\title{
Study of Endogenous Profile of hCG in Male Brazilian Athletes
}

\author{
Henrique M. G. Pereira, ${ }^{* a}$ Sandra B. Ramos, ${ }^{a}$ Marco Aurélio Dal Sasso, ${ }^{a}$ Elisa S. C. Poças, ${ }^{b}$ \\ Mônica C. Padilha, ${ }^{a}$ Luis Nelson F. Gomes ${ }^{a}$ and Francisco R. de Aquino Neto ${ }^{a}$
}

\author{
${ }^{a}$ Laboratório Controle de Dopagem, LADETEC, Instituto de Química, Centro Tecnologia, bloco A, $7^{\circ}$ andar and \\ ${ }^{b}$ Departamento de Farmacologia Básica e Clínica, Instituto de Ciências Biomédicas, \\ Universidade Federal do Rio de Janeiro, Ilha do Fundão 21941-590 Rio de Janeiro-RJ, Brazil
}

\begin{abstract}
No mundo das drogas de otimização de desempenho, hormônio gonadotrófico humano (hCG) é crescentemente usado sozinho em também em combinação com ciclos de Agentes Anabólicos Esteróides. Em homens o hCG mimetiza o hormônio Luteinizante (LH) e ajuda a aumentar a produção de testosterona nos testículos. Assim sendo, hCG é comumente usado durante e depois de ciclos de esteróides para restaurar o tamanho testicular assim como a produção de testosterona endógena. Controle de dopagem para hCG requer atenção especial, visto que, deve ser feita diferença entre a origem endógena e exógena de ambas substâncias. Na carência de um padrão mais claro do que seria um nível esperado de normalidade, os laboratórios de controle de dopagem tem aplicado valores de corte entre 5 e $25 \mathrm{mUI} / \mathrm{mL}$. Por causa de grande diferença em desenhos de ensaios e especificidade para diferentes formas de hCG, as concentrações medidas são altamente dependentes do ensaio usado e população analisada. O objetivo do estudo é o estabelecimento do valor de corte para a caracterização do abuso exógeno por atletas obtido com a aplicação do Imunoensaio Enzimático por Micropartículas.
\end{abstract}

In the world of performance enhancing drugs, human Chorionic Gonadotrophin (hCG) is increasingly used alone and also in combination with various Anabolic Androgenic Steroid cycles. In males, hCG mimics luteinizing hormone ( $\mathrm{LH})$ and helps increase testosterone production in the testes. As such, hCG is commonly used during and after steroid cycles to maintain and restore testicular size as well as endogenous testosterone production. Doping control for hCG requires special attention since a difference must be made between the endogenous and exogenous origin of both substances. In the absence of a clearer pattern of what would be an expected level of normality, the doping control laboratories have been applying cut off values between 5 and $25 \mathrm{mUI} / \mathrm{mL}$. Because of the large differences in assay design and specificity for different forms of hCG, the concentrations measured arehighly dependent on the assay used and population analyzed. The aim of the study is the establishment of a cut off value for the characterization of exogenous misuse by athletes obtained with the usage of Microparticles Enzyme Immunoassays.

Keywords: cut off value, doping control, human chorionic gonadotrophin, immunoassay

\section{Introduction}

Human Chorionic Gonadotrophin (hCG) is classified in the annual WADA's prohibited list in section S.3 as one of the peptide hormones used as doping by athletes. ${ }^{1}$

The misuse of this hormone by male athletes has basically two purposes: $i$ ) to stimulate the endogenous secretion of testosterone (T), maintaining the testosterone/

*e-mail: henriquemarcelo@iq.ufrj.br epitestosterone (T/E) ratio unchanged and ii) regression of the testicular atrophy due to anabolic steroids misuse. Since hCG is an endogenous substance, to consolidate an adverse analytical finding (AAF), a strategy is necessary which allows to discrimination of the hCG naturally produced from the one exogenously administrated. Following WADA's recommendation, an hCG AAF can be established only if the analyzed urine shows that the hormone concentration is higher than the expected one. Meanwhile, in the absence of a clearer pattern of what would be an "expected level", doping control laboratories have been applying cut off 
values between 5 and $25 \mathrm{mIU} / \mathrm{mL}$, sometimes with no clear statistical basis.

Another factor that must be considered is the diversity of available immunoassays for the detection of hCG which may use different epitopes. Such a fact creates the necessity of considering not only the population studied but also the methodology applied in the establishment of a criterion of evaluation. This way, the evidence of the exogenous misuse must fall back to the detection of levels that exceed an interval of reference previously established for a certain population when analyzed through a determined analytical method. ${ }^{2}$

The aim of the actual study is the establishment of a cut off value for the characterization of an $\mathrm{AAF}$ through the statistical examination of the profile of urinary excretion of hCG in male athletes obtained with the usage of Microparticles Enzyme Immunoassays (MEIA-Abbott System). Since the MEIA technique was originally developed for plasma analysis, a full validation protocol was done aiming to evaluate the performance of the assay in urine analysis.

\section{Experimental}

\section{Quality control protocol}

The analyses were accomplished after procedure of periodical maintenance and calibration according to specifications of the manufacturer. In each analytical batch, hCG controls were analyzed in $25 \mathrm{mIU} / \mathrm{mL}$ and $100 \mathrm{mIU} / \mathrm{mL}$ plasma concentrations. The controls should fall in an interval of $30 \%$ of the nominal values to the analytical batch be considered acceptable.

\section{Antibody specificity}

The antibody used in the procedure is classified as a Total Antibody $\beta$-hCG (Anti- $\beta C$ terminal + anti $-\beta 1$ ), with specificity to the hCG cleaved, intact and $\beta$ free unit.

\section{Validation}

The method was validated through the calculation of the sensitivity, specificity, linearity, exactness, repeatability and robustness according to protocol suggested by the Guideline of Validation of Analytical and Bioanalytical Methods deliberation RE 899, May 29th, 2003, National Agency of Sanitary Vigilance (ANVISA), Health Ministry. ${ }^{3}$

\section{Results}

The method was validated for analysis of human urine through protocol recommended by ANVISA, obtaining repeatability lower than $10 \%$ in this matrix to the concentration level of $1 \mathrm{mU} / \mathrm{mL}$ or higher. To the level of $0.5 \mathrm{mU} / \mathrm{mL}$ the repeatability was $15 \%$, so this concentration was considered as the quantification limit. The recovery was between 100 and $120 \%$. Linearity was evaluated considering the concentrations $0.5,1,3,5,10$, 25, 50 and $100 \mathrm{mIU} / \mathrm{mL}$, obtaining a equation curve (y $=1.176 \mathrm{x}-0.1074)$ and the coefficient of determination $\left(\mathrm{r}^{2}\right)>0.99$ (Figure 1). The robustness of the method was evaluated through urine analysis with $\mathrm{pH}$ and/or density altered, endogenous steroid profile demonstrating bacterium degradation and raised sedimentation. Of all the criteria evaluated, the presence of sediment showed a great interference in the results, which indicates that the centrifugation step is critical for the elimination of the noise derived from the matrix. However, considering the diversity of the Brazilian population, the sampling involved Caucasian, Afro-American and Indo-American descendents. One thousand two hundred and forty six $(1,246)$ male athletes had their urines analyzed by the MEIA technique for Total hCG (Abbott IMx) after previous centrifugation. For each analytical batch, hCG controls in plasma with concentrations of $25 \mathrm{mIU} / \mathrm{mL}$ (Figure 2) and $100 \mathrm{mIU} / \mathrm{mL}$ were tested showing a maximum variation

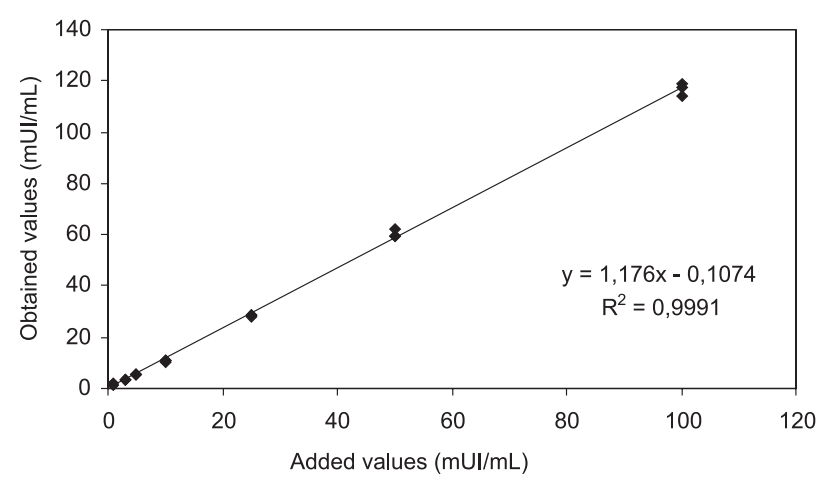

Figure 1. Linearity of the hCG MEIA Abbott System assay in fortified urine.

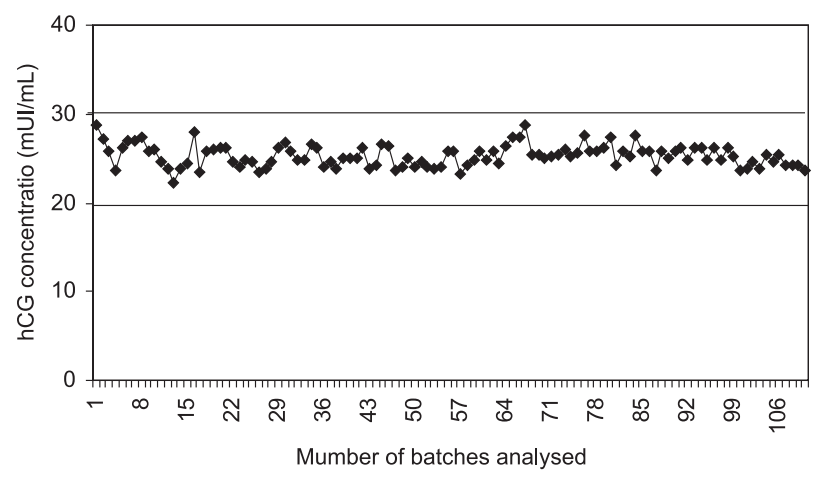

Figure 2. Control of the batches analyzed in the hCG $25 \mathrm{mUI} / \mathrm{mL}$ concentration. 
of $30 \%$, as specified by the manufacturer. An abnormal level of hCG resulting in some false-positives had been described for blood analysis with commercial available immunoassays, including the Abbott System. ${ }^{4}$ Some reasons have been presented for these results such as cross reactivity, ${ }^{5}$ lack of dilution protocol, ${ }^{4}$ presence of auto- and heterophilic antibodies in serum. ${ }^{6}$ In our tests, the presence of sediments still seems to be the most significant factor for the elevation of the background in procedures involving urine analysis with MEIA. The manufacturer stipulates $5 \mathrm{mIU} / \mathrm{mL}$ as the detection limit in plasma analysis. All the results above this value $(1.25 \%)$ were reanalyzed three more times. In all those samples the obtained results were below $1 \mathrm{mIU} / \mathrm{mL}$.

The step of the statistical approach is critical for the establishment of the cut off value. The choice of the approach depends on the distribution profile of the population. The target population was evaluated for normal distribution through D' Agostino \& Pearson and ShapiroWilk tests. Those tests demonstrated that the distribution showed a non-normal profile (Figure 3).

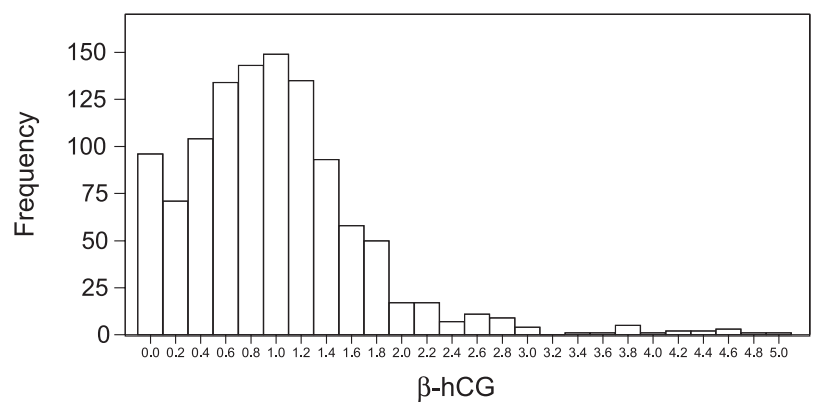

Figure 3. Non-normal distribuition profile of values of urinary concentrations from male Brazilian athletes $(\mathrm{p}<0.0001)$ obtained by MEIA technique (Abbott System).

This fact led to the adoption of a non-parametric approach on the evaluation of the results.Briefly, nonparametric methods do not rely on the estimation of parameters of the population as the mean or the standard deviation. All commonly used non-parametric tests rank the outcome variable from low to high and then analyze the ranks.

The estimate for a cut off value for hCG analyzed by the MEIA $\beta$-hCG total technique, was obtained through two different approaches $i$ ) the inference of a far outside value and $i$ ) the calculation of the reference interval. The calculation of the extreme value was previously used by Delbeke et al. ${ }^{7}$ on the analysis of the profile of hCG excretion in athletes and is based on the evaluation of the population interquartile. In the studied population, the interquartile interval was $0.32 \mathrm{mIU} / \mathrm{mL}$. The extreme value was then calculated through the equation ([percentile $75 \%+(3 \mathrm{x}$ interquartile interval]) obtaining the value of $2.38 \mathrm{mIU} / \mathrm{mL}$, comparable to $2.28 \mathrm{mIU} / \mathrm{mL}$ found by Delbeke et al..$^{7}$ Independently, the reference intervals of the population were calculated through the estimate of the inter-fractal interval (95\%). Once again, the non-parametric approach was utilized as suggested by the Specialists Panel in interval values of reference of IFCC and by the Committee of Patronizing Reference Values of ICSH. ${ }^{8,9}$ The reference value obtained was $3.06 \mathrm{mIU} / \mathrm{mL}$ with a confidence interval at $90 \%$ of (2.83-3.87). It seems that the value $5 \mathrm{mIU} / \mathrm{mL}$ is superior either to the extreme value as well as to the reference value considering the population and the method utilized. This fact suggests $5 \mathrm{mIU} / \mathrm{mL}$ as the candidate for a cut off value, since the $10 \mathrm{mIU} / \mathrm{mL}$ could lead to an increased index of false negative results.

\section{Conclusion}

Male athletes use hCG aiming to increase the production of endogenous testosterone. The evidence of the exogenous misuse must fall back to the detection of levels that exceed an interval of reference previously established for a certain population when analyzed through a determined analytical method. Two statistical approaches were used. Both traditionally applied to calculate reference intervals for clinical parameters among the human population and formerly used for doping control cut off value definitions. The approach of the inference of the "far outside value" gave a concentration of $2.38 \mathrm{mIU} / \mathrm{mL}$ and the calculation of the reference interval gave a value of $3.06 \mathrm{mIU} / \mathrm{mL}$ with a confidence interval at $90 \%$ of (2.83-3.87). Therefore, the suggested cut off value of $5 \mathrm{mIU} / \mathrm{mL}$ is suitable for determining an adverse analytical finding, considering the population of Brazilian athletes and the MEIA (Abbott System) technique.

\section{References}

1. World Anti-Doping Agency; The 2005 prohibited list, Montreal, 2005.

2. Kicman, A. T.; Brooks, R. V.; Cowan, D. A.; Br. J. Sport. Med. 1991, 25, 73 .

3. National Health Surveillance Agency (ANVISA); Health Ministry, Administrative rule_RDC n ${ }^{\circ} 210$. Avaiable at http://www.anvisa.gov.br/legis/resol/2003/rdc/210_03rdc.pdf. Access in 23/8/2007.

4. Cole, L. A.; Khanlian, S. A.; Clin. Biochem. 2004, 37, 344.

5. Ketchum, C.; Maclaren, N.; Jensen, J.; Phillips, I.; Weiner, R.; Kappy, M.; Clin. Chem. 1982, 28, 1998.

6. Marks, V. Clin. Chem. 2002, 48, 2008. 
7. Delbeke, F. T.; Van Eenoo, P.; Becker, P.; Int. J. Sports Med. 1998, 19, 287.

8. Solberg, H. E.; J. Int Fed Clin Chem. 1993, 5, 160.

9. International Federation of Clinical Chemistry (Expert Panel on Theory of Reference Values); J. Clin. Chem. Clin. Biochem. 1987, 25, 645 .

Received: May 24, 2007 Web Release Date: March 7, 2008 